\title{
Chemistry and pharmacological diversity of quinoxaline motifs as anticancer agents
}

\author{
OLAYINKA O. AJANI* \\ MARTINS T. NLEBEMUO \\ JOSEPH A. ADEKOYA \\ KEHINDE O. OGUNNIRAN \\ TOLUTOPE O. SIYANBOLA \\ CHRISTIANA O. AJANAKU \\ Department of Chemistry \\ Covenant University, CST, Canaanland \\ Km 10 Idiroko Road, P.M.B. 1023, Ota \\ Ogun State, Nigeria
}

\begin{abstract}
Surpassing heart diseases, cancer is taking the lead as the deadliest disease because of its fast rate of spreading in all parts of the world. Tireless commitment to searching for novel therapeutic medicines is a worthwhile adventure in synthetic chemistry because of the drug resistance predicament and regular outbreak of new diseases due to abnormal cell growth and proliferation. Medicinal chemistry researchers and pharmacists have unveiled quinoxaline templates as precursors of importance and valuable intermediates in drug discovery because they have been established to possess diverse pharmacological potentials. Hence, this review highlights the current versatile routes to accessing functionalized quinoxaline motifs and harnessing their documented therapeutic potentials for anticancer drug development.
\end{abstract}

Keywords: quinoxaline, anticancer activity, pharmacophore

\section{INTRODUCTION}

Cancer is a predicament that has received considerable attention as a top-rated killer disease, which is responsible for over $70 \%$ cases of mortality in less developed countries. Based on the consistent rise in the statistical data on cancer related deaths, it has been forecast that 11.5 million deaths will be recorded by the year 2030 (1). Cancers mainly occur as a result of mutagenicity in the gene encoding DNA. This results in the abnormal cell trait leading to rapid spread of abnormal cells that destroy neighboring tissues and could quickly spread to other parts of the body (2). Outbreak of tumor-related multidrug resistance (MDR) is a crucial reason for the widely reported failure rate in cancer therapy. The incidence of resistance among commercially available anticancer drugs has created more avenues for further quest for newer molecular entities for the therapeutic fight against cancer (3). The extra mass of tissues formed when cells are proliferating abnormally where they are not required are called tumors. They may be either benign or malignant, and the latter are cancerous and require disease control and prevention (4). According to molecular mechanisms, imidazolquinoxalines have been reported to show strong anticancer potential, which resulted from TNF- $\alpha$ production impairment through activation of p38MAPK

\footnotetext{
*Correspondence; e-mail: ola.ajani@covenantuniversity.edu.ng
} 
pathway and inhibition of PI3K pathway in the L929 murine fibroblast cell line (5). Thymidine kinase 1 (TK1) and thymidine phosphorylase (TYMP) are key molecular targets of thymidine therapeutics in cancer treatment. Hence, cytosolic thymidine pathways have been documented to be a highly effective tool in the modulation of anticancer activity of a thymidine quinoxaline conjugate (6). In view of the adverse effect of this global phenomenon, various researchers have synthesized numerous nitrogen containing heterocyclic compounds as agents of transformation in anticancer motifs in the chemotherapeutic world. For instance, some commercially available anticancer heterocycles include benzimidazole-based nocodazole (7), quinazoline-based KYS05090 (8), pyrimidine-based 5-fluorouracil and quinoline-based camptothecin (9).

Over the years, heterocycles have been the largest areas of research in organic chemistry. Numerous biologically relevant compounds such as most of the phytochemicals and secondary metabolites as well as nucleotides contain heterocyclic rings. Quinoxaline falls into the class of benzodiazines and it has its heteroatomic nitrogen located at positions 1and 4- of the heterocyclic nucleus (10). Latest information has unveiled quinoxaline nucleus as a privileged template among nitrogen-based heterocycles owing to its numerous valuable chemical properties (11), utilization in materials science research (12) and diverse pharmacological potentials (13). Hence, it is worthwhile targeting a review at quinoxaline as a dynamic heterocyclic compound to open more windows of opportunities among anticancer drugs.

\section{PHYSICAL PROPERTIES OF QUINOXALINE}

Quinoxaline (also 1,4-benzodiazine, 1,4-diazinaphthalene, 1,4-naphthyridine, benzoparadiazine, $\mathrm{C}_{8} \mathrm{H}_{6} \mathrm{~N}_{2}, M_{\mathrm{r}} 130.15$ ) is a low melting solid. It melts at $29-32{ }^{\circ} \mathrm{C}$ just above room temperature. Its boiling point is $220-223^{\circ} \mathrm{C}$. It is weakly basic $\left(\mathrm{p} K_{\mathrm{a}} 0.60\right)$. It is miscible with water and has a density of $1.124 \mathrm{~g} \mathrm{~mL}^{-1}$ at $25{ }^{\circ} \mathrm{C}$ (14). Quinoxaline frameworks are frequently reported to be from synthetic sources. Incorporation of at least one phenyl moiety in quinoxaline, as well as a structurally related heterocycle such as phenazine, increases the total number of resonance hybrids for such quinoxaline derivatives (4).

\section{OVERVIEW OF CANCER}

Cancer could be described as a compounded disorder that could be traceable elementarily to an environmental phenomenon. Carcinogens have been reported to be encountered by people through their exposure to water, air, chemicals, sunlight and food (15). It is interesting to note that more than $90 \%$ of cancers happen in the epithelia since epithelial cells cover a significant part of the body such as skin, respiratory and alimentary tracts. They also play a crucial role in metabolizing the ingested carcinogens (16). Mutations of the protein-encoding genes which control cell division are often responsible for the discrepancy and anomalies in cancer cells. This is because the proteins that are responsible for repairing worn-out cells and DNA damage are made by malfunctioning genes, which genes are also mutated. Treatment of cancer cells with DNA2 inhibitors recapitulates phenotypes observed upon DNA2 depletion, including reduced DNA double-strand break end resection and attenuation of HR repair. Similarly to genetic ablation of DNA2, chemical inhibition of DNA2 selectively attenuates the growth of various cancer cells with oncogene-induced replication stress (17). 
Inconsistent with the highly regulated physiological processes in normal cells, cancer cells undergo autonomous metabolic reprogramming to maintain rapid growth and proliferation and escape from growth suppressors and cell death signaling. Numerous cell signaling pathways are implicated in the induction and maintenance of epithelial mesenchymal transition (EMT), such as TGF-beta, Wnt/beta-catenin, Notch and oncogenic Src or Ras signaling (18), and the zinc finger E-box binding homeobox (ZEB) family transcriptional factors involved in the EMT processes are ZEB1 and ZEB2. Cancer is recognized by the uninhibited development of cells without differentiation caused by the de-regulation of proteins controlling cell division, cell multiplication and, also some critical enzymes (17). Recently, low protein diets have been reported to be associated with lowered cancer incidence and mortality risk of cancers in humans. In murine models, protein restriction inhibits tumor growth via the mTOR signaling pathway. IGF-1, amino acid metabolic programing, FGF21, and autophagy may also serve as potential mechanisms of protein restriction mediated cancer prevention (19). The dietary intervention aimed at reducing protein intake can be beneficial and has the potential to be widely adopted and effective in preventing and treating cancers (19). The beneficial role of low protein diets in tumor growth and cancer outcomes has been observed in numerous studies. For example, the result of a study showed a $70 \%$ inhibition of tumor growth in the castrate-resistant LuCaP23.1 prostate cancer model and a $56 \%$ inhibition in the WHIM16 breast cancer model fed a $7 \%$ protein diet when compared to an isocaloric $21 \%$ protein diet (20).

\section{Causes of cancer}

There are diverse causes of cancer which are noted to be complicated in nature, comprising factors in the ecosystem and cells. Considerable attention has been directed towards unveiling the major causes of cancer, some of which are herein underlined as tobacco smoke carcinogens, alcohol consumption, dietary factors, body mass and obesity, physical inactivity and inherited genetic abnormality.

Tobacco smoke carcinogens. - Statistical estimation has shown that cigarette consumption is accountable for the annual mortality rate of over one million human beings via lung cancer and diverse other neoplasms. Mutation loads are usually greater with an excess of $\mathrm{G}$ to $\mathrm{T}$ transversions among cancers traceable to smoking, which in turn results in higher frequency of p53 mutations (2). According to a recent study, the risk of conditional breast cancer specific death rate was on the increase amidst female population with recurring smoking habits compared to women that never smoke $(21,22)$.

Alcohol consumption. - It has been asserted that alcohol consumption plays a crucial role in the recent drastic increase in cancer cases $(23,24)$. According to the summary of a review, heavy alcohol consumption (more than four bottles per day) was significantly related to elevated risk of cancer associated with mouth and alimentary canals (24). Although the biological mechanism is not yet fully understood, the report on an epidemiological study supports the verdict which says high alcoholic consumption causes cancerous cells manifestation in seven crucial parts of the human body (25). A study on drinking and health risk clearly showed that the risk of death from liver diseases caused by alcohol consumption skyrocketed (Fig. 1) after consumption of a couple of drinks per day (26).

Dietary factors. - People's daily feeding habits have a direct impact on either averting or conferring risks. Improvement of daily fruit and vegetables intake cannot be overem- 


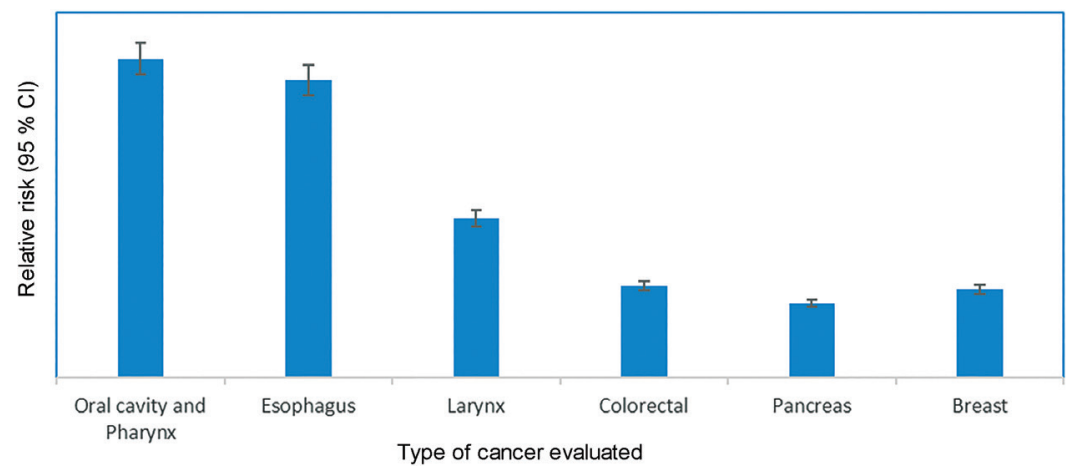

Fig. 1. Heavy alcohol consumption and the risk of selected cancers. Estimates for alcohol consumption of 4 or more drinks per day vs. non/occasional drinkers, except for pancreatic (i.e., $\geq 3$ drinks per day vs. non/occasional drinkers) and breast (i.e., $\geq 4.5$ drinks per day vs. non-drinkers) cancers; SD bars, $n=3$ (drawn based on raw data from ref. 24). CI - confidence interval.

phasized in the promotion of a healthy diet in order to prevent and avert insurgence of abnormal cell proliferation, chronic diseases and various disorders (27). Total cholesterol, triglyceride levels and glycaemic load should be monitored and controlled in breast cancer risk populations because they may be associated with increased risk. High intake of polyphenol/phyto-oestrogen-rich food (i.e., flavonoids, soya products), as well as fibers, fruits and vegetables, may have potential protective effects against breast cancer occurrence but the results might vary according to hormonal status (28).

Evidence of the relationship between dietary habits and cardiovascular disorder risks among the middle-aged population and elderly persons has been reported in literature (28). Factors contributing to the reduction of cardiovascular disease and cancer incidence would contribute tremendously to improvements in health and longevity (29).

Body mass and obesity. - Body mass and obesity provide estimated statistics of roughly twenty percent of documented cancerous cell issues (30). Excess body mass might have a direct or indirect effect on cancer risk in some ways. Surplus body fat may have a direct impact on the immune system dependent factors, inflammation and the amount of some hormonessuch as insulin and estrogen. It can also affect factors that control cell growth and hormonal regulatory proteins that regulate effective utilization of such hormones by the body system (31). Weight gain in already diagnosed breast cancer patients was reported to increase the risk, while weight loss might reduce the risk (32).

Physical inactivity. - Improvement in the quality of life of subjects after the diagnosis of breast cancer (33) and bladder cancer (34) was documented to be directly related to physical activity (35). Life survival among the physically active mature female population diagnosed with breast cancer could be efficiently improved by lower estrogen levels in such subjects; though there are insufficient data to support this hypothesis (36).

Inherited genetic abnormality. - There have been cases showing that genetic abnormality inherited by the subjects could be an underlying factor in many cancer cases. Most cancerous cells result from genetic structural changes due to a lack of control mechanisms responsible for the prevention of cancerous cell development (37). The gene encoding portion of 
cancer was found to have the ability to cluster in families $(38,39)$. Cancers are considered to be hereditary in nature and are related to the sudden change in the appearance of inherited genes. Inherited breast cancers are known to occur earlier in life compared to sporadic types which are known to be non-inherited (40). Abnormalities in the cell cycle progression are caused by a disruption that resulted from the loss of functioning ability of tumor suppressor genes. Cancer is the crucial disease that the geneticists have been fighting against and is found to be hard to unveil at the molecular level. It is known to exist continuously in families (41).

\section{Demographic data}

Information about the incidence of some common cancers across various regions of the world has been reported (42) and the results are shown in Table I.

Table I. Estimated age-standardized incidence and mortality rates per 100,000 subjects in different world areas

\begin{tabular}{|c|c|c|c|c|c|}
\hline \multirow{2}{*}{ Continent } & \multirow{2}{*}{ Region } & \multicolumn{2}{|c|}{ Incidence } & \multicolumn{2}{|c|}{ Mortality } \\
\hline & & Male & Female & Male & Female \\
\hline \multirow{5}{*}{ Africa } & Eastern Africa & 121.2 & 125.3 & 105.4 & 95.9 \\
\hline & Central Africa & 88.1 & 96.7 & 78.5 & 75.6 \\
\hline & Northern Africa & 109.2 & 98.9 & 89.5 & 68.2 \\
\hline & Southern Africa & 235.9 & 161.0 & 172.1 & 108.1 \\
\hline & Western Africa & 92.0 & 123.5 & 80.1 & 91.2 \\
\hline \multirow{4}{*}{ Asia } & Eastern Asia & 222.1 & 158.1 & 155.5 & 87.3 \\
\hline & South-Central Asia & 99.7 & 110.8 & 78.0 & 71.7 \\
\hline & South-Eastern Asia & 143.9 & 141.7 & 112.3 & 89.4 \\
\hline & Western Asia & 152.8 & 119.5 & 113.9 & 74.3 \\
\hline \multirow{3}{*}{ North America } & Caribbean & 196.3 & 153.5 & 116.6 & 86.2 \\
\hline & Central America & 136.2 & 134.4 & 84.7 & 80.6 \\
\hline & North America & 334.0 & 274.4 & 122.4 & 91.5 \\
\hline \multirow[t]{2}{*}{ South America } & South America & 186.7 & 162.9 & 116.6 & 88.2 \\
\hline & $\begin{array}{c}\text { Central and Eastern } \\
\text { Europe }\end{array}$ & 259.2 & 184.2 & 181.5 & 94.0 \\
\hline \multirow[t]{3}{*}{ Europe } & Northern Europe & 292.3 & 249.5 & 134.6 & 99.7 \\
\hline & Southern Europe & 289.9 & 212.2 & 149.9 & 81.2 \\
\hline & Western Europe & 337.4 & 250.9 & 138.4 & 84.3 \\
\hline \multirow{4}{*}{ Australia } & Australia/New Zealand & 356.8 & 276.4 & 125.6 & 86.0 \\
\hline & Melanesia & 146.0 & 133.4 & 119.8 & 95.9 \\
\hline & Micronesia & 153.8 & 164.4 & 104.7 & 70.3 \\
\hline & Polynesia & 225.0 & 201.5 & 133.6 & 87.9 \\
\hline
\end{tabular}

\footnotetext{
a Source: ref. 37.
} 
Overall cancer incidence and mortality rates by sex across the world are shown in Table I. The sample population used per region is 100,000. The incidence rate for both sexes combined is more than 3 times as high in Australia/New Zealand (633.2) as that in central Africa (184.8). It was noticed that the incidence was consistently higher in male than in female subjects in all regions of Asia, Europe and the Caribbean, except for SouthCentral Asia where the incidence in females was higher than that in males by $11 \%$ o (Table I). There is less regional variability in mortality than in incidence. Male mortality rate is higher than that of females in all African sub-regions except in Western Africa where the reverse was the case. Overall, the highest mortality rate for men was found in Central and Eastern Europe while that of women was highest in Southern Africa (42). Cancer cases have been decreasing in several western countries, largely owing to improved treatment and increased awareness and early detection; rates continue to increase in many countries with more limited resources and health infrastructure, particularly in Central and South America and Eastern Europe.

Breast cancer in females and lung cancer in males are the most frequently diagnosed cancers and the leading cause of cancer death for each sex in both economically developed and developing countries, while lung cancer is preceded by prostate cancer as the most frequent cancer among males in economically developed countries (42).

\section{Types of cancer}

Cancer has been categorized using various parameters of paramount importance. Some of the main types of cancer have been estimated based on the number of deaths. The most commontypes discussed in this study include lung cancer, leukemia, colorectal cancer, liver cancer and breast cancer.

Lung cancer. - Lung cancer has been also referred to as pulmonary carcinoma. The highest factor that often results in lung cancer is smoking (43). It has been reported that the second hand smoking of radon and particulate matters related to air pollution agents such as benzene (44), formaldehyde (44) and diesel air pollutants (45) are other identified sources of lung cancer. The symptoms include consistent coughing, concise and interrupted breath, puffing sound, bloody spittle, continuous bronchitis and other chest pain related issues (46). Subjects with small cell lung cancer (SCLC) were reported to have stronger initial response to chemotherapy than those with non-small cell lung cancer (NSCLC) (47, 48) although they are both responsible for eighty-five percent of lung cancer (47).

Leukemia. - Leukemia originates from cells that are essential to new blood cell formation (49). Cells of these types are found in the bone marrow. Leukemia, having started in the soft inner parts of the bone, is then transported to other parts of the body through the blood stream (50). There are indications that any cell responsible for blood formation could change to leukemia. They can develop into one of the three main types of blood cells (51). Acute lymphocytic leukemia (ALL), also called acute lymphoblastic leukemia, progresses rapidly and if not treated could be fatal according to the findings of an earlier review (52). Some of the major causative agents of leukemia are the degree of exposure to radiation (53), exposure to hazardous chemicals (54), viral infections (55), certain inherited syndromes. Treatments for leukemia include chemotherapy, radiation therapy, targeted therapy, stem cell transplant (56).

Colorectal cancer. - Colorectal cancer can be described as a type of cancer that originates from either the colon or the rectum $(57,58)$. It was unveiled by epidemiological studies 
as the third most virulent class of cancer globally (59). Most colorectal cancers develop gradually over many years. Prior to the commencement of cancer development, a non-cancerous polyp on the inner wall of either colon or rectum often initiates tissue or tumor growth (60). There are certain risks that can cause this type of cancer. These include: the type of diet (eating meat cooked at high temperature might cause statistical odds of getting colorectal cancer), lack of physical exercise, obesity, smoking, high alcohol consumption, individual record of stomach inflammatory disease, genealogical record of colorectal cancer events, inherited syndromes (61) among others. Colorectal cancer has symptoms such as excessive blood loss through the rectum, mental exhaustion, weariness, fatigue, unwanted weight loss, hematochezia, cramps and abdominal pain (62). Prevention of colorectal cancer, primary or secondary (63), could involve screening of the population without symptoms of cancer or pre-cancer conditions (64).

Liver cancer. - Liver cancer incidence is more rampant in developing countries (65). Cases of $\mathrm{HBV}$ and $\mathrm{HCV}$ were reported to be a crucial risk factor for liver cancer, also known as hepatocellular carcinoma (66). Among the human population in developing countries, intake of contaminated food items possessing mycotoxins, aflatoxin, along with active hepatitis virus infection constitutes a salient risk (67). In addition to these, excessive alcohol intake is also among odds for liver cancer in industrialized nations of the world through the development of cirrhosis and alcoholic hepatitis (68). The early stage of liver cancer can be treated by surgery; however, the removal of affected tissues via radiofrequency, chemo-embolization or alcohol insertion could be alternative treatments to surgery (1).

Breast cancer. - Breast cancer is a form of tumor with malignant traits that originates in breast cells (69). One of the ways in which breast cancer can spread is via the lymph system, which is a salient point to comprehend breast cancer (70). Most breast cancers are cancers that originate from the epithelial cells which shape breast tissues and are referred to as carcinomas (71). This cancer can also be transferred genetically. Women who started menstruating early have a higher chance of this menace, probably due to the long lasting period of exposure to progesterone and estrogen (71). Other risk factors are alcohol consumption, physical inactivity. There are some steps that can be undertaken to reduce the risk.

\section{MALIGNANT TUMORS}

Formation and development of malignant tumors can start in cellular parts of any organ with a high tendency of involvement in replication. Tumors of epithelial tissue include sarcoma of soft tissues and bone, glioma (brain), leukemia and lymphoma (hematopoietic and lymphatic tissues). Carcinomas are the most frequent class (72). Cancer cells have the tendency to produce two types of tumors, either the non-cancerous (benign tumors) or cancerous type (malignant tumors). Malignant tumors, generally categorized as carcinomas and sarcomas (73), can grow rapidly and harmfully, thereby destroying parts of tissues and organs in proximity to the tumor site (74).

Progression of malignancy begins with mutation and proceeds through hyperplasia, dysplasia to in situ cancer and/or invasive cancer (75). A typical malignant tumor is malignant mesothelioma; some of its symptoms are painful abdomen, inflammation or accumulation of fluid in the abdomen, weight loss, nausea, vomiting and constipation. Reports 
have also shown that these malignant mesotheliomas are more common in men than women (76). The best way malignant mesothelioma can be prevented is by limiting the exposure to asbestos at home, workplace or even public places (77). These tumors can be diagnosed early using various spectroscopic techniques (78).

\section{QUINOXALINE - PRIVILEGED HETEROCYCLE}

Owing to the privileged nature of functionalized quinoxaline heterocycle, quinoxaline-carbohydrate hybrids have been designed and evaluated as new and selective agents of impact in cytotoxic activity and photochemically induced cleaving in DNA (79). Quinoxaline-based compound 1, coded as XK469, belongs to the class of quinoxalines with antitumor efficiency and is structurally related to compound $\mathbf{2}$, commonly called chloroquinoxaline sulfonamide, CQS (NSC-339004). Quinoxaline-based compounds $\mathbf{1}$ and $\mathbf{2}$ are both known as antineoplastic quinoxaline topoisomerase II inhibitors (80). Quinoxaline 1,4-diN-oxides (QdNOs) have manifold biological properties. Recent development of QdNOs, 3, 4 and 5 , which are non-toxic until they are activated in the hypoxic cell, opens a new era in anticancer drug discovery (81). Numerous quinoxaline frameworks are currently under preclinical as well as clinical trial studies to be considered in effective treatment of infectious diseases. Quinoxaline compound 6, coded as BMS345541, is a kinase inhibitor which is utilized as an anti-tumor agent (82), while quinoxaline 7, coded as NVP-BSK805, is being developed as a valuable candidate for treating tumors and polycythemia (83) (Fig. 2).<smiles>CC(Oc1ccc(Oc2cnc3ccc(Cl)cc3n2)cc1)C(=O)O</smiles>

XK469, compound 1

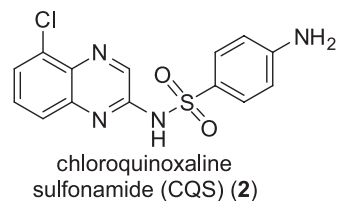

sulfonamide (CQS) (2)<smiles>N#Cc1c[n+]([O-])c2ccc(-c3ccc([N+](=O)[O-])cc3)cc2[n+]1[O-]</smiles>

2-cyano-7-(4-nitrophenyl)quinoxaline 1,4-dioxide (3)<smiles>CN(C)CCNc1c(C#N)[n+]([O-])c2cc(Cl)ccc2[n+]1[O-]</smiles>

6-chloro-3-cyano-2-((3-(dimethylamino) propyl)amino)quinoxaline 1,4-dioxide (5)

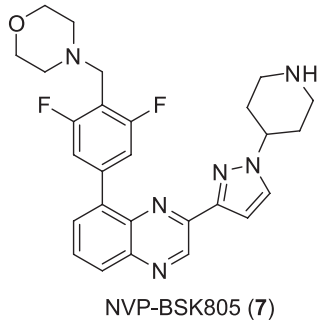<smiles>Cc1ccc2nc(NCCN)c3ccc(C)n3c2c1</smiles>

BMS-345541, compound 6 -( $\mathrm{N}$-acetylacetamido)-6-chloro-3-
cyanoquinoxaline 1,4-dioxide (4)

Fig. 2. Some quinoxaline-based drugs and drug-like candidates as anticancer agents (ref. 83). 


\section{NATURAL OCCURRENCE OF QUINOXALINES}

Quinoxaline is the valuable core structure found in echinomycin (8), which is a naturally occurring polypeptide antineoplastic antibiotic isolated from the bacterium Streptomyces echinatus. Echinomycin is known to be a strong inhibitor of RNA synthesis, which is attributed to its ability to bind to double-helical DNA. Echinomycin has also been isolated from Streptomyces lasalienis. It belongs to the family of quinoxaline antibiotics (84). There are interesting facts ascribable to this series of compounds due to the effective and efficient anticancer and antimicrobial activities they possess. Echinomycin biosynthesis, with the structure, as shown in Fig. 3, started with a molecule of quinoxaline-2-carboxylic acid (QC).

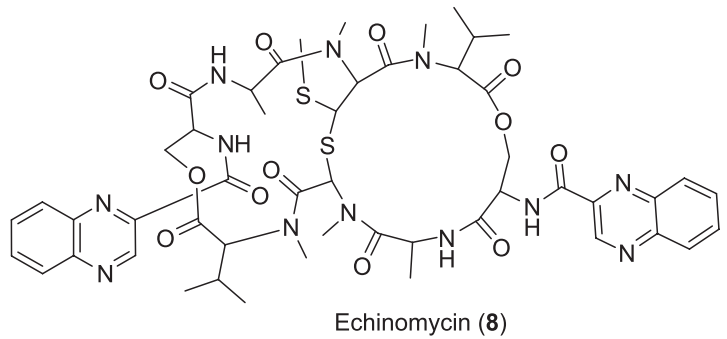

Fig. 3. Naturally occurring quinoxaline-based antibiotic and anticancer agent echinomycin (8).

L-tryptophan is the precursor of quinoxaline-2-carboxylic acid (QC) and its biosynthesis paralleled the first stage of nikkomycin biosynthesis (84). Quinoxaline is a benzopyrazine and this pyrazine ring system is found in the fungal metabolite aspergillic acid and in dihydro form in luciferin of several beetles including the firefly responsible for the chemiluminescence of this ostracod. Methoxypyrazine is a very important component of the aroma of many fruits and vegetables such as peas and Capsicum peppers, and also of wines (85).

\section{Synthesis of quinoxaline and its derivatives}

(i) Condensation reaction of $p$-substituted benzyl with $o$-phenylene diamines was reported to proceed readily and effectively using 0 -iodoxybenzoic acid (IBX) as catalyst at 25 ${ }^{\circ} \mathrm{C}$ to furnish 2,3,6-trisubstituted quinoxaline derivative (9), as shown in Scheme 1 (86).

(ii) According to the previous findings from our laboratory, hydrazinolysis of quinoxaline-2,3-dione gave 3-hydrazinoquinoxalin-2(1H)-one (10), which subsequently underwent microwave-assisted reaction with indole-2,3-dione derivatives (isatin derivatives) to furnish<smiles>[R]c1ccc(C(=O)C(=O)c2ccc([R])cc2)cc1</smiles>

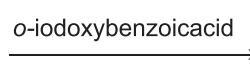

$\mathrm{CH}_{3} \mathrm{COOH}$, r.t.<smiles>[R]c1ccc(-c2nc3ccc([R])cc3nc2-c2ccc([R])cc2)cc1</smiles>

Scheme 1 
the corresponding quinoxalinone hydrazones, 3-(2-(5-substituted-2-oxoindolin-3-ylidene) hydrazinyl)quinoxalin-2(1H)-one (11) (in excellent yields at $400 \mathrm{~W}$ within $2 \mathrm{~min}$ ). The microwave assisted synthesis of isatin-based quinoxaline 11 is shown in Scheme $2(13,87)$.

(iii) In another study, microwave assisted reaction of 3-acetyl-2H-chromen-2-one derivatives and cyclohexanone derivatives with the earlier prepared 3-hydrazinoquinoxaline (10) led to the formation of hydrazones 3-(2-(1-(6-substituted-2-oxo-2H-chromen-3-yl)ethylidene)hydrazinyl)quinoxalin-2(1H)-one (12) and 3-(2-(2-substitutedcyclohexylidene) hydrazinyl)quinoxalin-2(1H)-one (13), resp., as expected. Formation of hydrazones 12 and 13 is shown in Scheme 3 (88).

(iv) 3-Hydrazinoquinoxaline (10) was also used in earlier microwave assisted organic synthesis (MAOS) to validate its facile condensation with 1,3-diketone and $\beta$-keto ester to produce 3-(3,5-disubstituted-1H-pyrazol-1-yl)quinoxalin-2(1H)-one (14) and 3-(3-substituted-5-oxo-4,5-dihydro-1H-pyrazol-1-yl)quinoxalin-2(1H)-one (15), resp., as shown in Scheme $4(87,89)$.<smiles>[R]c1ccc2c(c1)/C(=N/Nc1nc3ccc(OCC)cc3[nH]c1=O)C(=O)N2</smiles>

Scheme 2<smiles>[R]C1CCCC(=NNc2nc3ccccc3[nH]c2=O)C1C(=O)OCC(=O)O</smiles><smiles></smiles>

Scheme 3<smiles>[R]C1=NN(c2nc3ccccc3[nH]c2=O)C(=O)C1</smiles><smiles>NNc1nc2ccccc2[nH]c1=O</smiles>

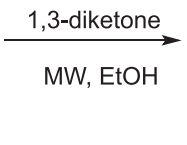<smiles>[R]c1cc([R1])n(-c2nc3ccccc3[nH]c2=O)n1</smiles>

Scheme 4<smiles>O=C(c1ccccc1)c1nc2ccccc2nc1-c1ccccc1</smiles><smiles>Nc1ccccc1N</smiles>
Phenanthrene-9,10-dione $\mathrm{C}_{2} \mathrm{H}_{5} \mathrm{OH}, \mathrm{H}_{2} \mathrm{O}$, r.t.<smiles></smiles>

Scheme 5 
(v) Design of a method essential for the synthesis of a quinoxaline-based candidate via the one-pot approach using [2-(sulfooxy)ethyl]sulfuric acid (SESA) was achieved as shown in Scheme 5 (90). When benzil was used as a dicarbonyl synthon, 2,3-diphenyl quinoxaline (16) was obtained, whereas utilization of phenanthrene-9,10-dione as dicarbonyl agent afforded dibenzo[a,c]phenazine (17) as shown in Scheme 5 (90).

\section{ANTICANCER EFFICACY OF QUINOXALINES}

\section{Quinoxaline screened for various cancer treatments}

Lung cancer. - From the class of quinoxaline scaffold screened against lung cancer cell lines, compound 18 exhibited promising activity as inhibitor of the $\mathrm{Wnt} / \mathrm{b}$-catenin signal route with $I C_{50}$ of $0.905 \mathrm{nmol} \mathrm{L}^{-1}$ (91). The lung cancer cell HOP-92 showed no growth in the presence of compound 19 at $1.0 \times 10^{-5} \mathrm{~mol} \mathrm{~L}^{-1}(92)$. Compound 20 was also documented to bring about growth inhibition in drug resistant cancerous cell lines of lung cancer (93) (Fig. 4).

Leukemia. - Series of quinoxalines were reported to show growth inhibitory activity against the leukemia cell lines HL-60 (with $75 \%$ of $G I_{50}$ values as low as 0.01 to $0.15 \mu \mathrm{mol} \mathrm{L}^{-1}$ ) (94).

However, compound 21 was the most active against the SR leukemia cell line with $I C_{50}$ $<0.01 \mu \mathrm{mol} \mathrm{L}-1$ (94, 95). Compound 22, possessing 3,4,5-trimethoxyanilino pharmacophore<smiles>Cc1ccc2nc(OCCC3CCCN3C)c(C#Cc3ccccc3)nc2c1</smiles>

6-methyl-2-(2-(1-methylpyrrolidin-2-yl) ethoxy)-3-(phenylethynyl)quinoxaline

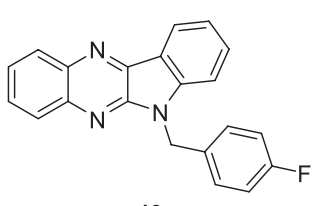

19

6-(4-fluorobenzyl)-6H-indolo $[2,3-b]$ quinoxaline<smiles>COc1cc(OC)cc(N2CCN(C(=O)Nc3nc4cc(F)ccc4nc3OC)CC2)c1</smiles>

4-(3,5-dimethoxyphenyl)- $N$-(7-fluoro-3-methoxy quinoxalin-2-yl)piperazine-1-carboxamide

Fig. 4. Selected quinoxalines with promising activity in lung cancer treatment.

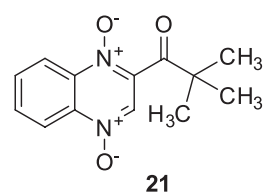

2-pivaloylquinoxaline 1,4-dioxide<smiles>COc1cc(Nc2nc3cc(N)cc(N)c3nc2-c2ccccc2)cc(OC)c1OC</smiles>

3-phenyl- $N^{2}$-(3,4,5-trimethoxyphenyl) quinoxaline-2,5,7-triamine<smiles>C[C@H](Oc1ccc(Oc2cnc3ccc(Cl)cc3n2)cc1)C(=O)O</smiles>

23

(R)-2-(4-((7-chloroquinoxalin-2yl)oxy)phenoxy)propanoic acid

Fig. 5. Selected quinoxalines with promising activity in leukemia treatment. 
at position 2 of the ring system, exhibited inhibition of leukemia cell lines HL-60 and MOLT-4 at nanomolar concentrations $(95,96)$. 2-Oxypropionic acid framework played a significant role in improving antitumor activity observed in quinoxaline template 23 against the leukemia cell line HL-60 (96) (Fig. 5).

Colorectal cancer. - Compound $\mathbf{2 4}$ was highly potent against three colon cancer cell lines: HCT 116 p53+/+, HCT p53-/- and HT 29 with their respective $I C_{50}$ of $0.40 \pm 0.01$, $0.30 \pm 0.07$ and $0.30 \pm 0.06 \mu \mathrm{mol} \mathrm{L}^{-1}$ (97). Tricyclic quinoxaline 25 was reported to inhibit the growth of LS174T colon cancer cells with $I C_{50}$ of $4.12 \pm 0.67 \mu \mathrm{mol} \mathrm{L}^{-1}$ and it was well tolerated without apparent side effects (98). Out of the library of quinoxaline derivatives, substituted dihydroquinozalin-2-one (26), synthesized from a copper-catalyzed coupling reaction, was the most potent with $I C_{50}$ of $4.96 \mu \mathrm{mol} \mathrm{L}^{-1}$ against the HeLaS3 cancer cell line (99) (Fig. 6).

Breast cancer. - Breast cancer is most common in mature female populations worldwide (100). According to a study, the quinoxaline derivative 27 inhibited the growth of breast cancer neoplasms and over 50 tumor cell lines (101). Quinoxaline-1,4-dioxide 28 was reported to stop abnormal growth in breast cancer cell lines with enhanced efficacy (102). Compound 29 showed remarkable efficiency against the breast cancer cell line MCF-7 as well as in skin related carcinogenesis based on in vivo investigation in mice (103) (Fig. 7).

Liver cancer. - All newly synthesized compounds were investigated on the human liver cell line (HEPG2). Compound $\mathbf{3 0}$ emerged as the most potent of this series with $I C_{50}$<smiles>O=C(NNc1nc2cccc(F)c2n2cccc12)c1cnccn1</smiles>

24

$N^{\prime}$-(9-fluoropyrrolo[1,2-a]quinoxalin-4-yl) pyrazine-2-carbohydrazide

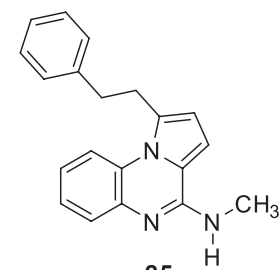

25

$N$-methyl-1-phenethylpyrrolo [1,2-a]quinoxalin-4-amine<smiles>O=C1Nc2ccc(Cl)cc2N2CCCCC12</smiles>

26

2-chloro-7,8,9,10-tetrahydro-5Hpyrido[1,2-a]quinoxalin-6(6aH)-one

Fig. 6. Selected quinoxalines with promising activity in colorectal cancer treatment.<smiles>Cc1c(C(=O)/C=C/c2ccc(F)cc2)[n+]([O-])c2ccccc2[n+]1[O-]</smiles>

27

(E)-2-(3-(4-fluorophenyl)acryloyl)-3methylquinoxaline 1,4-dioxide<smiles>O=C(c1ccccc1)c1c(-c2ccccc2)[n+]([O-])c2cc(Cl)c(Cl)cc2[n+]1[O-]</smiles>

2-benzoyl-6,7-dichloro-3phenylquinoxaline 1,4-dioxide

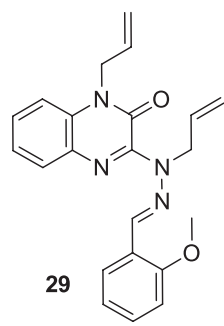

(E)-1-allyl-3-(1-allyl-2-(2-methoxybenzyli dene) hydrazinyl)quinoxalin-2(1H)-one

Fig. 7. Selected quinoxalines with promising activity in breast cancer treatment. 
<smiles>CCCOC(=S)Cc1ccc(S(=O)(=O)Nc2cnc3ccccc3n2)cc1</smiles>

30

o-propyl 2-(4-(N-(quinoxalin-2-yl)sulfamoyl) phenyl)ethanethioate<smiles>Cc1cccc(-c2c(C#N)[n+]([O-])c3ccc(C)cc3[n+]2[O-])c1</smiles>

3-cyano-6-methyl-2-(m-tolyl)quinoxaline 1,4-dioxide

Fig. 8. Selected quinoxalines with promising activity in liver cancer treatment.

of $4.29 \mu \mathrm{mol} \mathrm{L}-1$ (104). Quinoxaline motif 31 was reported to be potent against HEPG2 at $I C_{50}$ of $1.76 \mu \mathrm{mol} \mathrm{L}^{-1}$ (Fig. 8) according to a preliminary mechanism study (105). Degrees of dT-QX cytotoxicity, TYMP and TK1 proteins have been reported as good indicators of high anticancer activity of the thyme analogue of dT-QX, whose structure (32) is shown in Fig. 9 (6). The result of the cell viability 3-(4,5-dimethylthiazol-2-yl)-2,5-diphenyltetrazolium bromide (MTT) assay on four human liver cell lines was as shown in Fig. 9b, wherein the liver cell line HL-7702 exhibited the highest \% cell viability followed by Bel-7402 and the cell line with the lowest \% cell viability in MTT assay was Hep3B.

a)<smiles>Cc1cn(C2CC(n3cc(CNC(=O)CCCCCOc4ccc5c(c4)-c4nc6ccccc6nc4C4(C)CCCC(C)(C)C54C)nn3)C(CO)O2)c(=O)[nH]c1=O</smiles>

32

b)

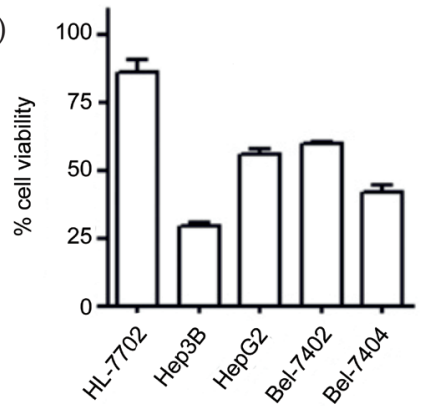

c)

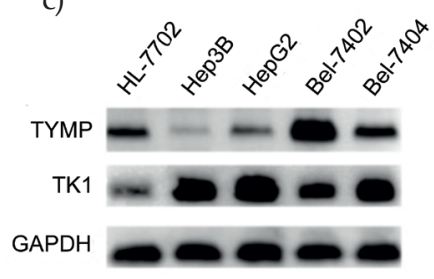

Fig. 9. Selected quinoxaline with promising activity in liver cancer treatment. Levels of dT-QX cytotoxicity and cellular TYMP and TK1 proteins in human liver cell lines. a) Chemical structure of thymidine analog dT-QX (32). b) Cell viability MTT assay on human liver cell lines including HL7702, Hep3B, HepG2, Bel-7402 and Bel-7404 after treatment of dT-QX at $50 \mu \mathrm{mol} \mathrm{L}^{-1}$ for $24 \mathrm{~h}$ (mean \pm SEM, $n=3$ ). c) Western blot analysis of TYMP and TK1 protein expression in HL-7702, Hep3B, HepG2, Bel-7402 and Bel-7404 liver cells (from ref. 6, with permission). 


\section{STRUCTURE-ACTIVITY RELATIONSHIP STUDY (SAR)}

The versatile activities of quinoxaline 1,4-di-N-oxides (QdNOs) are closely related to their chemical structures. The two $N$-oxide groups in the quinoxaline ring are necessary for the antitumor potential (106). In 2-alkylcarbonyl-3-trifluoromethylquinoxaline-1,4-di- $\mathrm{N}$-oxide derivatives, anticancer activity depends on the substituents in the carbonyl group. It improves in the order: ethyl < isopropyl < tert-butyl < phenyl-ones (107). SAR studies for QdNOs suggest that position $\mathrm{C}(2)$ of quinoxaline should be substituted by electron-withdrawing moieties, preferably by a nitrile or an aroyl, an ester, an $\mathrm{N}$-substituted amide group or a short brominated alkyl chain, for enhanced anticancer activity (108). Position C(3) is most often substituted by a short alkyl chain (e.g., $\mathrm{CH}_{3}, \mathrm{CF}_{3}$ ) or phenyl. Substitution of $\mathrm{C}(6)$ or $\mathrm{C}(7)$ of $\mathrm{QdNO}$ by $\mathrm{Cl}, \mathrm{F}, \mathrm{CF}_{3}$, or $\mathrm{OCH}_{3}$ is also advantageous in antitumor diversity (81).

\section{CONCLUSIONS}

Adverse effects and causes of cancer and tumor related diseases are expatiated in the study. Quinoxalines have, indeed, brought about considerable improvement and encouragement to human efforts in the fight against cancer. In addition, exploration of quinoxaline systems is unavoidable owing to their wide therapeutic applications. The present overview has revealed how quinoxaline and its derivatives have been used to inhibit the growth of cancer and tumor cells. Hence, due to the vast array of information gathered in the applications of quinoxaline in oncology, it is a warfare arsenal that may be developed into therapeutically important new-generation anticancer agents and serve possible future drug discovery.

Acronyms. - ALL - acute lymphocytic leukemia, CQS - chloroquinoxaline sulfonamide, DNA deoxyribonucleic acid, EMT - epithelial mesenchymal transition, HBV - hepatitis B virus, HCV - hepatitis $C$ virus, IBX - o-iodoxybenzoic acid, IC - inhibitory concentration, MAOS - microwave assisted organic synthesis, MDR - multi-drug resistance, MTT - 3-(4,5-dimethylthiazol-2-yl)-2,5-diphenyltetrazolium bromide, NSCLC - non-small cell lung cancer, QdNOs - quinoxaline 1,4-di- $N$-oxides, QC quinoxaline-2-carboxylic acid, RNA - ribonucleic acid, SAR - structure-activity relationship, SCLC small cell lung cancer, TK1 - thymidine kinase 1, TYMP - thymidine phosphorylase, ZEB - zinc finger E-box binding homeobox

Acknowledgments. - OOA gratefully acknowledges The World Academy of Sciences for the sponsorship of this work under the TWAS Research Grant for individual scientist programme (Grant No. 14-069 RG/CHE/AF/AC_1). All authors thank Covenant University for supporting this work.

\section{REFERENCES}

1. World Health Organization, Cancer Control: Knowledge into Action. WHO Guide, Geneva 2005; http:// www.who.int/cancer; last access date November 27, 2017.

2. M. R. Alison, The Cancer Handbook, Nature Publishing Group, London 2002.

3. M. Shaharyar, M. M. Abdullah, M. A. Bakht and J. Majeed, Pyrazoline bearing benzimidazoles: Search for anticancer agent, Eur. J. Med. Chem. 45 (2010) 114-119; https://doi.org/10.1016/j.ejmech.2009.09.032

4. K. M. Amin, M. M. Ismail, E. Noaman, D. H. Soliman and Y. A. Ammar, New quinoxaline 1,4-di-Noxides. Part 1: Hypoxia-selective cytotoxins and anticancer agents derived from quinoxaline 1, 4-diN-oxides, Bioorg. Med. Chem. 14 (2006) 6917-6923; https://doi.org/10.1016/j.bmc. 2006.06.038 
5. A. Courbet, N. Bec, C. Constant, C. Larroque, M. Pugniere, S. E. Messaoudi, Z. Zghaib, S. Khier, C. Deleuze-Masquefa and F. Gattacceca, Imidazoquinoxaline anticancer derivatives and imiquimod interact with tubulin: Characterization of molecular microtubule inhibiting mechansims in correlation with cytotoxicity, PLoS ONE 12 (2017) e0182022; https://doi.org/10.1371/journal.pone.0182022

6. Q. Wei, H. Liu, H. Zhou, D. Zhang, Z. Zhang and Q. Zhou, Anticancer activity of a thymidine quinoxaline conjugate is modulated by cytosolic thymidine pathways, BMC Cancer 15 (2015) 159 (11 pages); https://doi.org/10.1186/s12885-015-1149-5

7. Q. Guan, C. Han, D. Zuo, M. Zhai, Z. Li, Q. Zhang, Y. Zhai, X. Jiang, K. Bao, Y. Wu and W. Zhang, Synthesis and evaluation of benzimidazole carbamates bearing indole moieties for antiproliferative and antitubulin activities, Eur. J. Med. Chem. 87 (2014) 306-315; https://doi.org/10.1016/j.ejmech.2009.09.032

8. H. K. Rim, S. Cho, D. H. Shin, K. S. Chung, Y. W. Cho, J. H. Choi, J. Y. Lee and K. Lee, T-Type Ca ${ }^{2+}$ channel blocker, KYS05090 induces autophagy and apoptosis in A549 cells through inhibiting glucose uptake, Molecules 19 (2014) 9864-9875; https://doi.org/10.3390/molecules 19079864

9. C. H. Tseng, Y. L. Chen, P. J. Lu, C. N. Yang and C. C. Tzeng, Synthesis and antiproliferative evaluation of certain indeno[1,2-c]quinoline derivatives, Bioorg. Med. Chem. 16 (2008) 3153-3162; https:// doi.org/10.1016/j.bmc.2007.12.028

10. O. O. Ajani and O. C. Nwinyi, Synthesis and evaluation of antimicrobial activity of phenyl and furan-2-yl[1,2,4]triazolo[4,3-a]quinoxalin-4(5H)-one and their hydrazone precursors, Can. J. Pure Appl. Sci. 3 (2009) 983-992.

11. V. M. Lakshmi, F. F. Hsu, H. A. J. Schut and T. V. Zenser, Stability and reactivity of 2-nitroso amino-3,8-dimethylimidazo[4,5-f]quinoxaline, Chem. Res. Toxicol. 19 (2006) 325-333; https://doi. org/10.1021/tx050305x

12. R. B. K. Siram, J. Smith, T. D. Anthopoulos and S. Patil, Acenaphtho[1,2-b]quinoxaline based low band gap copolymers for organic thin film transistor applications, J. Mat. Chem. 22 (2012) 4450-4458; https://doi.org/10.1039/C1JM13540F

13. O. O. Ajani, C. A. Obafemi, O. C. Nwinyi and D. A. Akinpelu, Microwave assisted synthesis and antimicrobial activity of 2-quinoxalinone-3-hydrazone derivatives, Bioorg. Med. Chem. 18 (2010) 214-221; https://doi.org/10.1016/j.bmc.2009.10.064

14. S. Srivastava, J. Banerjee and N. Srestha, Quinoxaline as a potent heterocyclic moiety, IOSR J. Pharm. 4 (2014) 17-27; https://doi.org/10.9790/3013-040120101617027

15. M. Veiraj and D. Sowmya, A review on cancer screening, Int. J. PharmTech. Res. 9 (2016) 224-233.

16. M. Ghouari, The relationship between food and cancer, Int. J. Innov. Appl. Stud. 8 (2014) 1814-1830.

17. S. Kumar, X. Peng, J. Daley, L. Yang, J. Shen, N. Nguyen, G. Bae, H. Niu, Y. Peng, H-J. Hsieh, L. Wang, C. Rao, C. C. Stephan, P. Sung, G. Ira and G. Peng, Inhibition of DNA2 nuclease as a therapeutic strategy targeting replication stress in cancer cells, Oncogenesis 6 (2017) e319; https://doi.org/10.1038/ oncsis.2017.15

18. R. Derynck, B. P. Muthusamy and K. Y. Saeteurn, Signaling pathway cooperation in TGF-beta-induced epithelial-mesenchymal transition, Curr. Opin. Cell Biol. 31 (2014) 56-66; https://doi. org/10.1016/j.ceb.2014.09.001

19. J. Yin, W. Ren, X. Huang, T. Li and Y. Yin, Protein restriction and cancer, Biochim. Biophys. Acta 1869 (2018) 256-262; https://doi.org/10.1016/j.bbcan.2018.03.004

20. L. Fontana, R. M. Adelaiye, A. L. Rastelli, K. M. Miles, E. Ciamporcero, V. D. Longo, H. Nguyen, R. Vessella and R. Pili, Dietary protein restriction inhibits tumor growth in human xenograft models of prostate and breast cancer, Oncotarget 4 (2013) 2451-2461; https://doi.org/10.18632/oncotarget.1586

21. S. D. Boone, K. B. Baumgartner, R. N. Baumgartner, A. E. Connor, E. M. John, A. R. Giuliano, L. M. Hines, S. N. Rai, E. C. Riley, C. M. Pinkston, R. K. Wolff and M. L. Slattery, Active and passive cigarette smoking and mortality among Hispanic and non-Hispanic white women diagnosed with invasive breast cancer, Ann. Epidemiol. 25 (2015) 824-831; https://doi.org/10.1016/j.annepidem.2015.08.007 
22. H. Parada, P. T. Bradshaw, S. E. Steck, L. S. Engel, K. Conway, S. L. Teitelbaum, A. I. Neugut, R. M. Santella and M. D. Gammon, Postdiagnosis changes in cigarette smoking and survival following breast cancer, JNCI Cancer Spect. 1 (2017) Article ID pkx001 (8 pages); https://doi.org/10.1093/jncics/ pkx001

23. J. Connor, Alcohol consumption as a cause of cancer, Addiction 112 (2017) 222-228; https://doi. org/10.1111/add.13477

24. C. Pelucchi, I. Tramacere, P. Boffetta, E. Negri and C. La Vecchia, Alcohol consumption and cancer risk, Nutr. Cancer 63 (2011) 983-990; https://doi.org/10.1080/01635581.2011.596642

25. V. Bagnardi, M. Rota, E. Botteri, I. Tramacere, F. Islami, V. Fedirko, L. Scotti, M. Jenab, F. Turati, E. Pasquali, C. Pelucchi, C. Galeone, R. Bellocco, E. Negri, G. Corrao, P. Boffetta and C. La Vecchia, Alcohol consumption and site-specific cancer risk: a comprehensive dose-response meta-analysis, Br. J. Cancer 112 (2015) 580-593; https://doi.org/10.1038/bjc.2014.579

26. P. Bofetta and L. Garfinkel, Alcohol drinking and mortality among men enrolled in an American Cancer Society prospective study, Epidemiology 1 (1990) 342-348.

27. M. Kotepui, Diet and risk of breast cancer, Contemp. Oncol. 20 (2016) 13-19; https://doi.org/10.5114/ wo.2014.40560

28. R. E. Rossi, M. Pericleous, D. Mandair, T. Whyand and M. E. Caplain, The role of dietary factors in prevention and progression of breast cancer, Anticancer Res. 34 (2014) 6861-6875.

29. X. Wang, Y. Ouyang, J. Liu, M. Zhu, G. Zhao, W. Bao and F. B. Hu, Fruit and vegetable consumption and mortality from all causes, cardiovascular disease, and cancer: systematic review and dose-response meta-analysis of prospective cohort studies, Br. Med. J. 349 (2014) Article ID g4490 (14 pages); https://doi.org/10.1136/bmj.g4490

30. K. Y. Wolin, K. Carson and G. A. Colditz, Obesity and cancer, Oncologist 15 (2010) 556-565; https:// doi.org/10.1634/theoncologist.2009-0285

31. A. P. Coll, Effects of pro-opiomelanocortin (POMC) on food intake and body weight: mechanisms and therapeutic potential? Clin. Sci. (London) 113 (2007) 171-182; https://doi.org/10.1042/CS20070105

32. C. M. Dieli-Conwright, K. Lee and J. L. Kiwata, Reducing the risk of breast cancer recurrence: An evaluation of the effects and mechanisms of diet and exercise, Curr. Breast Cancer Rep. 8 (2016) 139_ 150; https://doi.org/10.1007/s12609-016-0218-3

33. B. Yan, L. M. Yang, L. P. Hao, C. Yang, L. Quan, L. H. Wang, Z. Wu, X. P. Li, Y. T. Gao, Q. Sun and J. M. Yuan, Determinants of quality of life for breast cancer patients in Shanghai, China, PLoS ONE 11 (2016) Article ID e0153714 (14 pages); https://doi.org/10.1371/journal.pone.0153714

34. M. Keimling, G. Behrens, D. Schmid, C. Jochem and M. F. Leittzmann, The association between physical activity and bladder cancer: a systematic review and meta-analysis, Br. J. Cancer 110 (2014) 1862-1870; https://doi.org/10.1038/bjc.2014.77

35. J. Gerritsen and A. Vincent, Exercise improves quality of life in patients with cancer: a systemic review and meta-analysis of randomized controlled trials, Br. J. Sport Med. 50 (2016) 796-803; https:// doi.org/10.1136/bjsports-2015-094787

36. M. D. Holmes, W. Y. Chen, D. Feskanich, C. H. Kroenke and G. A. Colditz, Physical activity and survival after breast cancer diagnosis, J. Am. Med. Assoc. 293 (2005) 2479-2486; https://doi.org/10.1001/ jama.293.20.2479

37. B. Alberts, A. Johnson, J. Lewis, M. Raff, K. Roberts and P. Walter, Molecular Biology of the Cell, $4^{\text {th }}$ ed., Garland Science, New York 2002.

38. N. Mavaddat, A. C. Antoniou, D. F. Easton and M. Garcia-Closas, Genetic susceptibility of breast cancer, Mol. Oncol. 4 (2010) 174-191; https://doi.org/10.1016/j.molonc.2010.04.011

39. P. D. Pharaoh, J. M. Lipscombe, K. L. Redman, N. E. Day, D. F. Easton and B.A. Ponder, Familial predisposition to breast cancer in a British population: implications for prevention, Eur. J. Cancer 36 (2000) 773-779; https://doi.org/10.1016/S0959-8049(00)00023-X 
40. U. Krug, A. Ganser and H. P. Koeffler, Tumor suppression genes in normal and malignant hematopoiesis, Oncogene 21 (2002) 3475-3495; https://doi.org/10.1038/sj/onc/1205322

41. N. Mavaddat, A. M. Dunning, B. A. Ponder, D. F. Easton and P. D. Pharaoh, Common genetic variation in candidate genes and susceptibility to subtypes of breast cancer, Cancer Epidemiol. Biomarkers Prev. 18 (2009) 255-259; https://doi.org/10.1158/1055-9965.EPI-08-0704

42. A. Jemal, F. Bray, M. M. Center, J. Ferlay, E. Ward and D. Forman, Global cancer statistics, CA Cancer J. Clin. 61 (2011) 69-90; https://doi.org/10.3322/caac.20107

43. M. Furrukh, Tobacco smoking and lung cancer, Sultan Qaboos Univ. Med. J. 13 (2013) 345-358.

44. X. Q. Jiang, X. D. Mei and D. Di Feng, Air pollution and chronic airway diseases: what should people know and do? J. Thorac. Dis. 8 (2016) E31-E40; https://doi.org/10.3978/j.issn.2072-1439 .2015.11.50

45. United States Environmental Protection Agency, Health Assessment Document for Diesel Engine Exhaust, USEPA Washington DC, 2002; http://cfpub.epa.gov/ncea/cfm/ recordisplay.cfm?deid=29060; last access date November 30, 2017.

46. P. Farbicka and A. Nowicki, Palliative care in patients with lung cancer, Contemp. Oncol. 17 (2013) 238-245; https://doi.org/10.5114/wo.2013.35033

47. S. Ahn, S. H. Hwang, J. Han, Y. L. Choi, S. H. Lee, J. S. Ahn, K. Park, M. J. Ahn and W. Y. Park, Transformation to small cell lung cancer of pulmonary adenocarcinoma: clinicopathologic analysis of six cases, J. Pathol. Transl. Med. 50 (2016) 258-263; https://doi.org/10.4132/jptm.2016.04.19

48. M. G. Oser, M. J. Niederst, L. V. Sequist and J. A. Engelman, Transformation from non-small-cell lung cancer to small-cell lung cancer: molecular drivers and cells of origin, Lancet Oncol. 16 (2015) Article ID e165-172; https://doi.org/10.1016/S1470-2045(14)71180-5

49. B. Gholipour, Leukemia: Types, symptoms and treatment, Live Sciences Publication, Paris; http:// www.livescience.com/34763-leukemia-blood-cancer-bone-marrow-transplant.html; last access November 15, 2017.

50. M. Trendowski, The inherent metastasis of leukaemia and its exploitation by sonodynamic therapy, Crit. Rev. Oncol. Hematol. 94 (2015) 149-163; https://doi.org/10.1016/j.critrevonc.2014 .12.013

51. G. N. Waite, Blood and immunology. Chapter 9. Blood components in: Medical Physiology: Principles for Clinical Medicine, 3rd ed. (R. A. Rhoades and D. R. Bell, Eds.), Lippincott Williams and Wilkins, Baltimore 2009, pp. 169-171.

52. I. Z. Al-Mohsen, D. A. Sutton, L. Sigler, E. Almodovar, N. Mahgoub, H. Frayha, S. Al-Hajjar, M. G. Rinaldi and T. J. Walsh, Acrophialophora fusisipora brain abscess in a child with acute lymphoblastic leukemia: Review of cases and taxonomy, J. Clin. Microbiol. 38 (2000) 4569-4573.

53. R. Wakeford, M. P. Little and G. M. Kendall, Risk of childhood leukemia after low-level exposure to ionizing radiation, Expert. Rev. Hematol. 3 (2010) 251-254; https://doi.org/10.1586/ehm.10.25

54. M. M. Jacobs, T. F. Malloy, J. A. Tickner and S. Edwards, Alternatives assessment frameworks: Research needs for the informed substitution of hazardous chemicals, Environ. Health Perspect. 124 (2016) 265-280; https://doi.org/10.1289/ehp.1409581

55. J. B. Liao, Viruses and human cancer, Yale J. Biol. Med. 79 (2006) 115-122.

56. D. A. Pollyea, J. A. Gutman, L. Gore, C. A. Smith and C. T. Jordan, Targeting acute myeloid leukemia stem cells: A review and principles for the development of clinical trials, Haematologica 99 (2014) 1277-1284; https://doi.org/10.3324/haematol.2013.085209

57. M. Riihimäki, A. Hemminki, J. Sundquist and K. Hemminki, Patterns of metastasis in colon and rectal cancer, Sci. Rep. 6 (2016) Article ID 29765; https://doi.org/10.1038/srep29765

58. M. Fleming, S. Ravula, S. F. Tatishchev and H. L. Wang, Colorectal carcinoma: Pathologic aspects, J. Gastrointest. Oncol. 3 (2012) 153-173; https://doi.org/10.3978/j.issn.2078-6891.2012. 030

59. D. M. Parkin, S. L. Whelan, J. Ferlay, L. Teppo and D. B. Thomas (Eds.), Cancer Incidence in Five Continents, IARC Scientific Publications No. 155, International Agency for Research on Cancer, Lyon 2002, Vol. VIII. 
60. M. K. Mishra and K. S. Bishnupuri, Epigenetics of colorectal cancer, in: Epigenetic Advancements in Cancer, Springer International Publishing, New York 2016, pp. 98-99.

61. F. A. Haggar and R. P. Boushey, Colorectal cancer epidemiology: Incidence, mortality, survival, and risk factor, Clin. Colon Rectal Surg. 22 (2009) 191-197; https://doi.org/10.1055/s-0029-1242458

62. G. S. Cooper, F. Xu, J .S. B. Sloan, M. D. Schluchter and S. M. Koroukian, Prevalence and predictors of interval colorectal cancers in medicine beneficiaries, Cancer 118 (2012) 3044-3052; htto://doi. org/10.1002/cncr.26602

63. P. J. T. López, J. S. Albero and J. A. Rodríguez-Montes, Primary and secondary prevention of colorectal cancer, Clin. Med. Insights Gastroenterol. 7 (2014) 33-46; https://doi.org/10.4137/CGast. S14039

64. R. M. Jones, K. J. Devers, A. J. Kuzel and S. H. Woolf, Patient-reported barriers to colorectal cancer screening, Am. J. Prev. Med. 38 (2010) 508-516; https://doi.org/10.1016/j.amepre.2010.01.0 21

65. C. de Martel, D. Maucort-Boulch, M. Plummer and S. Franceschi, World-wide relative contribution of hepatitis B and C viruses in hepatocellular carcinoma, Hepatology 62 (2015) 1190-1200; https://doi. org/10.1002/hep.27969

66. H. B. El-Serag, Epidemiology of viral hepatitis and hepatocellular carcinoma, Gastroenterology 142 (2012) 1264-1273; https://doi.org/10.1053/j.gastro.2011.12.061

67. B. Kucukcakan and Z. Hayrulai-Musliu, Challenging role of dietary aflatoxin B1 exposure and hepatitis B infection on risk of hepatocellular carcinoma, Open Access Maced. J. Med. Sci. 3 (2015) 363-369; https://doi.org/10.3889/oamjms.2015.032

68. S. Lierena, M. T. Arias-Loste, A. Puente, J. Cabezas, J. Crespo and E. Fábrega, Binge drinking: Burden of liver disease and beyond, World J. Hepatol. 7 (2015) 2703-2715; https://doi.org/10.4254/wjh. v7.i27.2703

69. A. C. Wolff, A. L. Blackford, K. Visvanathan, H. S. Rugo, B. Moy, L. J. Goldstein, K. Stockerl-Goldstein, L. Neumayer, T. S. Langbaum, R. L. Theriault, M. E. Hughes, J. C. Weeks and J. E. Karp, Risk of marrow neoplasms after adjuvant breast cancer therapy: the national comprehensive cancer network experience, J. Clin. Oncol. 33 (2015) 340-348; https://doi.org/10.1200/JCO.2013.54.6119

70. G. N. Sharma, R. Dave, J. Sanadya, P. Sharma and K. K. Sharma, Various types and management of breast cancer: An overview, J. Adv. Pharm. Technol. Res. 1 (2010) 109-126.

71. M. D. Abeloff, A. C. Wolff, B. L. Weber, T. Z. Zaks, V. Sacchini and B. McCormick, Cancer of the breast, in Abeloff's Clinical Oncology, 4th ed. (M. D. Abeloff, J. O. Armitage, J. E. Niederhuber, M. B. Kastan and W. G. McKenna, Eds.), Elsevier Churchill Livingstone, Philadelphia 2008, pp. 1875-1943.

72. J. K. McLaughlin, W. J. Blot, S. S. Devesa and J. F. Fraumeni, Renal cancer, in: Cancer Epidemiology and Prevention, $2^{\text {nd }}$ ed. (D. Schottenfeld and J. F. Fraumeni, Eds.), Oxford University Press, New York 1996, pp. 1142-1155.

73. R. Schmieder, C. Delles and F. Messerli, Diuretic therapy and the risk for renal cell carcinoma, J. Nephrol. 13 (2000) 343-346.

74. T. A. Martin, L. Ye, A. J. Sanders, J. Lane and W. G. Jiang, Cancer invasion and metastasis: Molecular and cellular perspective, in: Metastasis Cancer: Clinical and Biological Perspectives (Ed. R. Jandial), Landes Bioscience, Austin (TX) 2013, pp. 135-168.

75. M. Andreeff, D. W. Goodrich and A. B. Pardee, Cell proliferation, differentiation, and apoptosis, in: Holland-Frei Cancer Medicine, 6th ed. (D. W. Kufe and R. E. Pollock, Eds.), BC Decker Publisher, Hamilton 2003, pp. 21-34.

76. N. Plato, J. I. Martinsen, P. Sparén, G. Hillerdal and E. Weiderpass, Occupation and mesothelioma in Sweden: updated incidence in men and women in the 27 years after the asbestos ban, Epidemiol. Health 38 (2016) e2016039 (25 pages); https://doi.org/10.4178/epih.e2016039

77. J. W. Lim, D. Koh, J. S. G. Khim, G. V. Le and K. Takahashi, Preventive measures to eliminate asbestos-related diseases in Singapore, Safety Health Work 2 (2011) 201-209; https://doi.org/10.5491/ SHAW.2011.2.3.201 
78. E. S. Lee and J. M. Lee, Imaging diagnosis of pancreatic cancer: A state-of-the-art review, World J. Gastroenterol. 20 (2014) 7864-7877; https://doi.org/10.3748/wjg.v20.i24.7864

79. K. Toshima, T. Ozawa, T. Kimura and S. Matsumura, The significant effect of the carbohydrate structures on the DNA photocleavage of the quinoxaline-carbohydrate hybrids, Bioorg. Med. Chem. Lett. 14 (2004) 2777-2779; https://doi.org/10.1016/j.bmcl.2004.03.065

80. H. Gao, E. F. Yamasaki, K. K. Chan, L. L. Shen and R. M. Snapka, DNA sequence specificity for topoisomerase II poisoning by the quinoxaline anticancer drugs XK469 and CQS, Mol. Pharmacol. 63 (2003) 1382-1388; https://doi.org/10.1124/mol.63.6.1382

81. G. Cheng, W. Sa, C. Cao, L. Guo, H. Hao, Z. Liu, X. Wang and Z. Yuan, Quinoxaline 1,4-di-N-oxides: Biological activities and mechanisms of actions, Front. Pharmacol. 7 (2016) 21 pages; https://doi. org/10.3389/fphar.2016.00064

82. J. Yang, K. I. Amiri, J. R. Burke, J. A. Schmid and A. Richmond, BMS-345541 target inhibitor of kB kinase and induces apoptosis in melanoma: Involvement of nuclear factor $\mathrm{kB}$ and mitochondria pathways, Clin. Cancer Res. 12 (2006) 950-960; https://doi.org/10.1158/1078-0432.CCR-05-1220

83. F. Baffert, C. H. Régnier, A. De Pover, C. Pissot-Soldermann, G. A. Tavares, F. Blasco, J. Brueggen, P. Chène, P. Drueckes, D. Erdmann, P. Furet, M. Gerspacher, M. Lang, D. Ledieu, L. Nolan, S. Ruetz, J. Trappe, E. Vangrevelinghe, M. Wartmann, L. Wyder, F. Hofmann and T. Radimerski, Potent and selective inhibition of polycythemia by the quinoxaline JAK2 inhibitor NVP-BSK805, Mol. Cancer Ther. 9 (2010) 1945-1955; https://doi.org/10.1158/1535-7163.MCT-10-0053

84. O. Watanabe and H. Oikawa, Diversification of echinomycin molecular structure by way of chemoenzymatic synthesis and heterologous expression of the engineered echinomycin biosynthetic pathway, Curr. Opin. Chem. Biol. 13 (2009) 189-196; https://doi.org/10.1016/j.cbpa. 2009.02.012

85. R. M. Rajukar, V. A. Agrawal, S. S. Thonte and R. G. Ingale, Heterocyclic chemistry of quinoxaline and potential activities of quinoxaline derivatives - A review, Pharmacophore 1 (2010) 65-76.

86. M. M. Heravi, K. Bakhtiari, M. H. Tehrami, N. M. Javadi and H. A. Oskooie, Facile synthesis of quinoxaline derivatives using o-iodoxybenzoic acid (IBX) at room temperature, Arkivoc 26 (2006) $16-22$.

87. O. O. Ajani, Present status of quinoxaline motifs: Excellent pathfinders in therapeutic medicine, Eur. J. Med. Chem. 85 (2014) 688-715; https://doi.org/10.1016/j.ejmech.2014.08.034

88. O. O. Ajani, C. A. Obafemi, C. O. Ikpo, K. O. Ajanaku, K. O. Ogunniran and O. O. James, Comparative study of microwave assisted and conventional synthesis of novel 2-quinoxalinone-3-hydrazone derivatives and its spectroscopic properties, Int. J. Phys. Sci. 4 (2009a) 156-164.

89. O. O. Ajani, C. A. Obafemi, C. O. Ikpo, K. O. Ogunniran and O. C. Nwinyi, Synthesis and antibacterial activity of some pyrazol-1-ylquinoxalin-2(1H)-one derivatives, Chem. Heterocycl. Comp. 45 (2009b) 1370-1378; https://doi.org/10.1007/s10593-010-0435-z

90. S. Sajjadifar, H. Noorizadeh, H. Veisi, O. Louie, M. Avval and M. Rezayati, A facile and efficient method for the synthesis of quinoxaline derivatives using [(sulfooxy) ethyl]sulfamic acid as a novel difunctional bronsted acid, recyclable and organocatalyst, Res. J. Pharm. Biol. Chem. Sci. 4 (2013) 906-916.

91. S. B. Lee, Y. I. Park, M. S. Dong and Y. D. Gong, Identification of 2,3,6-trisubstituted quinoxaline derivatives as a Wnt2/b-catenin pathway inhibitor in non-small-cell lung cancer cell lines, Bioorg. Med. Chem. Lett. 20 (2010a) 5900-5904; https://doi.org/10.1016/j.bmcl.2010.07. 088

92. S. S. Karki, R. Hazare, S. Kumar, V. S. Bhadauria, J. Balzarini and E. De Clercq, Synthesis, anticancer and cytostatic activity of some $6 H$-indolo [2,3-b] quinoxalines, Acta Pharm. 59 (2009) 431-440; https:// doi.org/10.2478/v10007-009-0040-9

93. Y. B. Lee, Y. D. Gong, H. Yoon, C. H. Ahn, M. K. Jeon and J. Y. Kong, Synthesis and anticancer activity of new 1-[(5- or 6-substituted 2-alkoxyquinoxalin-3-yl)aminocarbonyl]-4-(hetero)aryl piperazine derivatives, Bioorg. Med. Chem, 18 (2010b) 7966-7974; https://doi.org/10.1016/j.bmc.2010.09.028 
94. B. Zarranz, A. Jaso, I. Aldana and A. Monge, Synthesis and anticancer activity evaluation of new 2-alkylcarbonyl and 2-benzoyl-3-trifluoromethyl-quinoxaline 1,4-di- $\mathrm{N}$-oxide derivative, Bioorg. Med. Chem. 12 (2004) 3711-3721; https://doi.org/10.1016/j.bmc.2004.04.013

95. S. Piras, M. Loriga, A. Carta, G. Paglietti, M. P. Costi and S. Ferrari, Novel 3-benzoyl-2-piperazinylquinoxaline derivatives as potential antitumor agents, J. Heterocycl. Chem. 43 (2006) 541-548; https:// doi.org/10.1002/jhet.5570430304

96. S. T. Hazeldine, L. Polin, J. Kushner, K. White, T. H. Corbett and J. P. Horwitz, Synthetic modification of the 2-oxypropionic acid moiety in 2-\{4-[(7-chloro-2-quinoxalinyl)oxy] phenoxy\}propionic acid (XK469), and consequent antitumor effects. Part 4, Bioorg. Med. Chem. 13 (2005) 3910-3920; https:// doi.org/10.1016/j.bmc.2005.04.011

97. F. Grande, F. Aiello, O. De Grazia, A. Brizzi, A. Garofalo and N. Neamati, Synthesis and antitumor activities of a series of novel quinoxalinhydrazides, Bioorg. Med. Chem. 15 (2007) 288-294; https://doi. org/10.1016/j.bmc.2006.09.073

98. G. Moarbess, C. Deleuze-Masquefa, V. Bonnard, S. Gayraud-Paniagua, J. Vidal, F. Bressolle, F. Pinguet and B. Pierre-Antoine, In vitro and in vivo anti-tumoral activities of imidazo[1,2-a]quinoxaline, imidazo[1,5-a]quinoxaline, and pyrazolo[1,5-a]quinoxaline derivatives, Bioorg. Med. Chem. 16 (2008) 6601-6610; https://doi.org/10.1016/j.bmc.2008.05.022

99. S. Tanimori, T. Nishimura and M. Kirihata, Synthesis of novel quinoxaline derivatives and its cytotoxic activities, Bioorg Med Chem Lett. 19 (2009) 4119-4121; https://doi.org/10.1016/j. bmcl.2009.06.007

100. P. J. Kaboli, A. Rahmat, P. Ismail and K. H. Ling, Targets and mechanisms of berberine, a natural drug with potential to treat cancer with special focus on breast cancer, Eur. J. Pharmacol. 740 (2014) 584-595; https://doi.org/10.1016/j.ejphar.2014.06.025

101. U. Das, H. N. Pati, A. K. Panda, E. De Clercq and J. Balzarini, J. Molnár, Z. Baráth, I. Ocsovszki, M. Kawase, L. Zhou, H. Sakagami and J. R. Dimmock, 2-(3-Aryl-2-propenoyl)-3-methyl quinoxaline-1,4-dioxides: A novel cluster of tumor-specific cytotoxins which reverse multidrug resistance, Bioorg. Med. Chem. 17 (2009) 3909-3915; https://doi.org/10.1016/j.bmc. 2009.04.021

102. K. Ghattass, S. El-Sitt, K. Zibara, S. Rayes, M. Haddadin, M. El-Sabban and H. Gali-Muhtasib, The quinoxaline di-N-oxide DCQ blocks breast cancer metastasis in vitro and in vivo by targeting the hypoxia inducible factor-1 pathway, Mol. Cancer 13 (2014) 12-25; https://doi.org/10.1186/1476-459813-12

103. S. A. Galal, A. S. Abdelsamie, H. Tokuda, N. Suzuki, A. Lida, M. M. Elhefnawi, R. A. Ramadan, M. H. E. Atta and H. I. El Diwani, Part I: Synthesis, cancer chemopreventive activity and molecular docking study of novel quinoxaline derivatives, Eur. J. Med. Chem. 46 (2011) 327-340; https://doi. org/10.1016/j.ejmech.2010.11.022

104. M. M. Ghorab, F. A. Ragab, H. I. Heiba, M. G. El-Ghazzar and M. G. El-Ghazzar, Synthesis, in-vitro anticancer screening and radiosensitizing evaluation of some new $N$-(quinoxalin-2-yl) benzene sulfonamide derivatives, Arzneimittelforschung 62 (2012) 46-52; https://doi.org/10.1055/s-0031-1295496

105. Y. Hu, Q. Xia, S. Shangguan, X. Liu, Y. Hu and R. Sheng, Synthesis and biological evaluation of 3-aryl-quinoxaline-2-carbonitrile 1,4-di- $\mathrm{N}$-oxide derivatives as hypoxic selective anti-tumor agents, Molecules 17 (2012) 9683-9696; https://doi.org/10.3390/molecules17089683

106. B. Solano, V. Junnotula, A. Marin, R. Villar, A. Burguete, E. Vicente, S. Perez-Silanes, I. Aldana, A. Monge, S. Dutta, U. Sarkar and K. S. Gates, Synthesis and biological evaluation of new 2-arylcarbonyl-3-trifluoromethylquinoxaline 1,4-di-N-oxide derivatives and their reduced analogues, J. Med. Chem. 50 (2007) 5485-5492; https://doi.org/10.1021/jm0703993

107.B. Zarranz, A. Jaso, I. Aldana and A. Monge, Synthesis and anticancer activity evaluation of new 2-alkylcarbonyl and 2-benzoyl-3-trifluoromethyl-quinoxaline 1,4-di-N-oxide derivatives. Bioorg. Med. Chem. 12 (2004) 3711-3721; http://doi.org/10.1016/j.bmc.2004.04.013

108. J. Jampilek, Recent advances in design of potential quinoxaline anti-infectives, Curr. Med. Chem. 21 (2014) 4347-4373; https://doi.org/10.2174/0929867321666141011194825 